\title{
The European Union and democratization in Central and Southeastern Europe since 1989
}

\author{
Ulrich Sedelmeier
}

In Sabrina P Ramet and Christine M Hassenstab (eds) Central and Southeast

European Politics Since 1989, Second edition (Cambridge University Press, 2019), 539-562.

\begin{abstract}
A central tool of the European Union (EU) to promote the democratization of post-communist Europe have been the conditions it has attached to the offer of accession. Yet EU's influence varies across countries, and over time between the periods before and after accession. A key factor limiting the EU's democratizing impact are domestic costs of complying with the EU's conditionality: the more governments rely on illiberal and undemocratic means to maintain power, the less influence the EU has. Moreover, even if the domestic adjustment costs are not prohibitively high, for EU conditionality to bring about, or lock in democratic change, the positive and negative incentives relating to the benefits of EU membership have to be credible. The limited credibility of sanctions against backsliding in new members and of the reward of accession for current candidate countries in Southeastern Europe is a key explanation for the setback in the EU's democratizing role during this decade.
\end{abstract}

A distinctive feature of the democratic transition in Central and Southeastern Europe after 1989 has been its close link to the process of accession to the European Union (EU). The first wave of post-communist transition studies did not focus much on this characteristic of the process of 
democratization in East Central Europe (ECE). Instead, analyses focused predominantly on domestic factors to explain its outcome. ${ }^{1}$ From the early 2000s, the literature has studied much more explicitly the role of international organizations, and of the EU in particular. ${ }^{2}$ By now, the effects of the EU on democratization in post-communist Europe are certainly no longer 'a topic that remains mostly unexplored. ${ }^{3}$

And indeed, it is largely undisputed that the EU can potentially have a tremendous influence on post-communist transition. Here are two very different striking examples, albeit not directly with regard to democratization: the first, concerning a highly sensitive question of statehood, is the EU's ability to compel the Montenegrin leadership to set the threshold for the success of the referendum on independence at 55 percent, rather than 50 percent. Another often cited example is the June 1999 session of the Hungarian parliament that passed 152 of 180 laws without any debate since they concerned EU legislation. ${ }^{4}$ The literature broadly agrees that the main tool through which the EU exercises this influence on domestic politics is through accession conditionality. ${ }^{5}$

However, we have to be careful not to overstate the power of conditionality and the EU's actual impact on democratization. ${ }^{6}$ First, while the EU's influence on post-communist democratization was arguably strongest in the period up to the enlargements of 2004 and 2007, even during this period, its causal impact varied across countries, issues and over time. The main question for this chapter is therefore: how can we explain this variation in the EU's influence on democratization? Second, and more specifically, the EU's ability to influence candidate countries may not be easily replicable among the 
countries in Southeastern Europe (SEE) that have applied for EU membership. Despite initial improvements in the quality of democracy and the rule of law in SEE, there is stagnation and there is even a deterioration of democracy. How can we explain the apparent differences between accession candidates in ECE and SEE? Third, political developments in ECE during this decade raise questions about the enduring ability of the EU to influence democratization through its enlargement process. Signs of democratic 'backsliding' among the EU's post-communist new member states suggest that the EU's democratizing impact may not be sustainable after accession, when challenged by illiberal national governments. What is then the scope for the EU to redress backsliding among its membership once it has occurred?

This chapter discusses in turn each of these questions about the scope and limit of EU influence on democratization in Central and Southeastern Europe. It starts with an overview of the instruments through which the EU promotes democracy in its European neighborhood and identifies political conditionality, linked to the incentive of membership, as the most powerful instrument. Drawing on the vast literature about EU conditionality and Europeanization in Central and Southeastern Europe, it suggests that a key factor limiting the EU's democratizing impact are domestic adjustment costs to the EU's conditionality: the more governments rely on illiberal and undemocratic means to maintain power, the less influence the EU has. Moreover, even if the domestic adjustment costs are not prohibitively high, for EU conditionality to bring about, or lock in democratic change, the positive and negative incentives relating to the benefits of EU membership have to be credible. The limited credibility of sanctions against backsliding in new 
members and of the reward of accession for current candidate countries in SEE is a key explanation for the setback in the EU's democratizing role during this decade.

\section{Accession conditionality as the main EU instrument for democracy promotion in post-communist Europe}

The EU has a range of instruments through which it can promote democracy. Many of these instruments were specifically developed in the context of supporting democratic transition in post-communist Europe. They include financial support for activities that foster democracy such as the 1992 PHARE (Pologne Hongrie: aide à la restructuration économique) 'Democracy Program' that provided funding for civil society organizations that engaged in activities to promote an inclusive, pluralist, and participatory political culture, and since 1994, the European Initiative for Democracy and Human Rights. The most important instrument of the EU to promote democracy in European non-member states is its political conditionality. Conditionality consists of offering target states certain rewards for their compliance with specific conditions, such as democratic principles or human rights. The conditional benefits that the EU offers as rewards include: financial assistance and aid, such as the PHARE program; market access, for example through association agreements; and full membership in the EU. EU membership is the most powerful reward that the EU can offer for compliance with its conditions.

The EU's founding treaties specify only one condition that a state had to fulfill in order to apply for membership: it had to be European. The EU made the first reference to political membership conditions in the context of its 
Mediterranean enlargements. Elements of a democratic conditionality were visible in the EU's rejection of an application by General Franco's Spain for an association agreement in 1962, or the freezing of the association agreement with Greece in 1967 following the Colonels' coup. ${ }^{7}$ The most explicit statement of the political conditions of EU membership was the Declaration on Democracy adopted at the European Council in Copenhagen in 1978. It confirmed that "respect for and maintenance of representative democracy and human rights in each Member State are essential elements of membership." Although the occasion for the declaration was the impending first direct election to the European Parliament, it was also intended to provide the EU with a safeguard in case the candidate countries might revert to authoritarian rule after obtaining membership. ${ }^{9}$ The risk of return of authoritarianism was then arguably more salient in ECE than later as there was no dramatic challenge to democratic consolidation similar to the attempted putsch in Spain in 1981, but it did not lead the EU to codify the political conditions of membership in its treaty at that time.

The EU's use of conditionality with regard to human rights and democracy developed significantly in the context of eastern enlargement. PHARE aid was provided to post-communist countries only once they had achieved progress in democratic transition (which is also the reason why the acronym only refers to Poland and Hungary, the frontrunners of democratization in ECE). Conversely, the EU suspended aid for Romania in 1990 (along with negotiations for a trade agreement), for Yugoslavia in 1991, and Croatia in 1995. The EU also started to apply conditionality to trade agreements with post-communist states. The start of negotiations for the so- 
called "Europe Agreements" reflected differences in democratization across ECE. The EU took one step further in the context of negotiations with Romania. Concerns about democracy in Romania led the EU to discuss the inclusion of a suspension clause into the agreement to allow one party to terminate the agreement in reaction to violations of democracy and human rights in the other party. However, partly in order to point the finger less directly at Romania, the Council agreed in May 1992 that henceforth all cooperation and association agreements with CSCE members should contain such a suspension clause. In May 1995, the Council extended the suspension clause to agreements with any non-member state. In addition to these expansions of the use of conditionality in the EU's external relations with regard to trade and aid, the European Council in Copenhagen in June 1993 made a first direct statement of the political conditions for membership. The European Council declared for the first time that countries in ECE that so desired might eventually become members. To make this step acceptable to the member states that had been reluctant about an eastern enlargement, the European Council formulated a number of broad conditions that would-be members had to meet. In addition to the ability to apply EU legislation upon accession, a successful transition to a market economy, as well as the EU's own ability to absorb new members, the political conditions specified the need for "stable institutions guaranteeing democracy, the rule of law, human rights and respect for and protection of minorities."10

On the basis of these "Copenhagen criteria", political conditionality broadened considerably in its subsequent application by the Commission and the European Council. For example, the Commission's annual monitoring 
reports that formed the basis of decisions by the Council about the accession process included issues such as language training for non-citizens and prison conditions in Latvia, or the conditions of state-run orphanages in Romania. An example of how wide-ranging political conditions had become are the benchmarks that the Commission identified in 2008 for Macedonia to start accession negotiation: they included improved dialogue with political parties, reforms of the police, the legal sector, and of public administration, the fight against corruption, and electoral law reform. The EU's political conditions are generally most extensive with regard to the successor states of Yugoslavia, where they include issues related to the violent break-up of Yugoslavia and ethnic conflict, such as cooperation with the International Criminal Tribunal for the former Yugoslavia (ICTY), the return of refugees, regional cooperation and good neighborly relations, or a "normalization" of relations between Serbia and Kosovo.

The scope of the EU's political conditionality goes far beyond the rules covered by the EU treaty and that apply to its member states. This discrepancy has led to accusations of double standards in the treatment of candidates and full members. Partly as a result of the EU's vulnerability to such criticism, partly to increase the leverage of EU institutions over new members if democratic standards should slip after accession, the member states agreed to strengthen EU competences in these areas. An amendment in the Treaty of Amsterdam in 1997 stated that "the principles of liberty, democracy, respect for human rights and fundamental freedoms, and the rule of law" are preconditions for membership. It also specified procedures to suspend membership rights of a country for "serious and persistent" breaches 
of these principles (Article 7 TEU). Yet even with this treaty change, preaccession conditionality still extends far beyond the principles codified in the EU treaty.

\section{Variation in the EU's influence on democratization in ECE}

While the EU can be a pervasive force in the domestic politics of would-be members, there are also plenty of examples of the limits of the EU's influence. The EU's efforts to influence domestic politics continue to have little effect in Belarus, just as they were unsuccessful in Slovakia under the government of Vladimír Mečiar between 1994 and 1998, in Croatia under Franjo Tuđman (1990-99), or in Serbia under Slobodan Milošević (19892000). At the same time, it is hardly tenable to claim that, say, Poland, Hungary or the Czech Republic would not have democratized without the EU. How much influence does the EU then have on democratization, and how can we explain variation in this influence across different target countries?

Studies of EU accession conditionality share one main finding, namely that its influence depends on a favorable constellation of domestic factors. ${ }^{11}$ More specifically, the EU's influence depends primarily on target governments' cost/benefit calculations in response to the incentives provided by the EU. Moreover, there is also a fairly large consensus on which particular factors are most important for such cost/benefit calculations and hence for the effectiveness of conditionality: the size of the EU's incentives, the credibility of the EU's conditionality, and, crucially, the domestic adjustment costs for target governments. ${ }^{12}$ The first two factors are largely in the hands of the EU, while the last one is not; yet it depends precisely on 
favorable domestic conditions whether a country is susceptible to EU influence.

The main domestic condition are the adjustment costs of compliance with EU conditionality for target governments. These adjustment cost generally tend to be higher the lower a country's starting point with regard to prevailing democratic principles. More specifically, with regard to issues such as minority rights, domestic adjustment costs depend on the strength of nationalist parties in parliament. ${ }^{13}$ With regard to democratization, the costs entailed in meeting the EU's demand vary according to domestic party constellations, for which the literature distinguishes between liberal, illiberal, and mixed party constellations. ${ }^{14}$ While the adjustment costs were prohibitively high in illiberal constellations for the EU to have an influence, in liberal constellations, the EU was unnecessary for democratization. The EU's influence was therefore most significant in mixed constellations.

\section{Democratic frontrunners with liberal party constellations}

The democratic frontrunners in ECE - Hungary, Poland, the Czech Republic, Slovenia, Estonia, Latvia, Lithuania - generally followed a liberal trajectory ${ }^{15}$ and were characterized by a liberal party constellation in which the major parties agreed on liberal reforms and integration into Western international organizations. These countries began to democratize and to consolidate democracy without EU pressure and it is highly doubtful that they would not have democratized without the EU. The convergence between these governments' preferences for democratization and EU demands meant 
that, in these countries, the EU was without much causal influence on the broad patterns of democratic development. ${ }^{16}$

At the same time, the EU might still have an impact on specific aspects of democracy in these countries - especially with regard to questions of minority rights. Although the adjustment costs in this issue area were still considerable, but they were usually not prohibitively high for governments in countries with liberal party constellations. The general agreement on democratic principles among the main parties meant that minority rights did not threaten the basis on which a government maintained its power. The main examples here are Estonia and Latvia with their sizeable Russophone minorities. In these countries, the EU's use of conditionality was able to overcome even strong domestic opposition and reversed discriminatory policies, for example concerning the Latvian citizenship and language laws. Conversely, discrimination prevailed in areas where the EU did not make use of its conditionality, such as the electoral law and the education law in Latvia. $^{17}$ Examples in other countries range from the adoption of reforms of the Czech judicial system to the question of the segregation of the Roma population in the Czech town of Usti Nad Labem that the EU raised in 1999, or EU criticism of the freedom of the media in Hungary in the early years after the fall of communism.

\section{Authoritarian/nationalist governments in illiberal party constellations}

At the other end of the spectrum are countries that were dominated by nationalist, authoritarian or populist regimes, or where governments relied on authoritarian practices to stay in office. There are not many countries in ECE 
in which such regimes have held power uninterruptedly since 1989 . Belarus is probably the only case, while in other countries such as Slovakia under Mečiar, Croatia under Tuđman, or Serbia under Milošević, nationalist/authoritarian regimes were in power only temporarily.

In illiberal domestic party constellations, the EU also had very little impact on democratization while nationalist or authoritarian elites were in power. For these elites, the political adjustment costs of complying with the EU's requirements with regard to democracy were potentially prohibitively high. ${ }^{18}$ As the EU's conditions threatened to undermine the very basis of their rule, the leadership of such countries was immune to EU pressure. In the case of Belarus under President Aleksander Lukashenko, the EU combined the positive incentives of democratic conditionality with sanctions, such as breaking off high level political contact between the EU and Belarus in 2004, a visa ban and freezing of assets of the country's main leaders, or the suspension the Generalized System of Preferences on trade. Since then there have been episodes of an easing of sanctions in response to democratic improvements, such as a release of political prisoners in 2008, and peaceful elections in 2015, punctuated by a freezing of relations after crackdowns on opposition, such as after the presidential election in 2010 . In sum, there has been some modest progress, especially after the Lukasheko regime looked for a rapprochement in 2017 . As a strategy to diversify economic relations away from an exclusive focus on Russia, the regime came to place a higher value on closer relations with the EU. But progress remains limited to areas that do not threat to undermine the regime's hold on office. 
Fragile democracies with mixed party constellations

Arguably, the EU's impact on democratic consolidation was most pronounced in those states in which nationalist or authoritarian forces lost power to liberal forces, such as in Slovakia (after the September 1998 elections), Croatia (temporarily, after the January 2000 elections), Serbia (temporarily, after the overthrow of Milošević in October 2000 and after the July 2008 elections), or Romania (after the November 1996 elections). Once more liberal opposition parties assumed power, the EU's conditionality - if combined with a credible accession perspective - had a lock-in effect that endured subsequent changes in government. ${ }^{19}$

For democratic, reform-oriented forces that had been in opposition, the compliance costs with regard to the EU's political conditionality might still have been high, but they did not threaten their very power basis. If these forces formed the government and adopted reforms demanded by the EU, and the EU rewarded compliance with further steps towards integration, the political opportunity structure for subsequent governments changed. As long as the electorate expected benefits from EU membership, future governments faced costs if they attempted to roll back the democratic reforms of their predecessors and thereby slow down progress on the path to European integration. By the same token, progress towards EU membership through democratic reform also created incentives for nationalist parties in opposition to moderate their platforms. ${ }^{20}$ In order to win re-election, they had to reassure the electorate that they would not endanger the progress made toward EU membership. 
Examples of such dynamics include Romania, where democratization improved significantly after a reform coalition replaced the first postcommunist government of Ion lliescu following the 1996 elections, but where democratic performance was maintained after Iliescu and his Social Democratic Party $\left(\mathrm{PDSR}^{21}\right)$ returned to power in 2000. Maybe the clearest example is Slovakia, after Mečiar and the Movement for a Democratic Slovakia (HZDS ${ }^{22}$ ) lost the 1998 elections to a broad coalition of liberal democratic parties. The new government, led by Mikuláš Dzurinda, rapidly complied with the EU's democratic conditions that corresponded to its own priorities of political reform. It met the EU's demands for municipal elections, a charter for municipal self-government, direct elections of the president, and involvement of opposition parties in parliamentary appointments. In the area of minority rights, it established a parliamentary committee and a government council, and passed a law on the use of minority languages, which was the last precondition for start accession negotiations with the EU. ${ }^{23}$ The 2006 elections brought to power Robert Fico's Direction - Social Democracy party $\left(\mathrm{SMER}^{24}\right)$, in coalition with the nationalist Slovak National Party and Mečiar's (renamed) People's Party - Movement for a Democratic Slovakia (L'S HZDS ${ }^{25}$ ). However, despite some of the rhetoric, there has not been a significant democratic backsliding in practice. ${ }^{26}$

A similar example is Croatia after Tuđman's death and the defeat of the Croatian Democratic Union $\left(\mathrm{HDZ}^{27}\right)$ in the parliamentary election in 2000. The liberal democratic coalition government formed by Ivica Račan made strong progress toward starting EU accession negotiations, although some of the EU's conditions still imposed high costs - notably regarding cooperation 
with the ICTY, which included the extradition of generals indicted for war crimes that large parts of the population considered to be heroes. The HDZ returned to power after the 2003 elections, but had moderated its platform while in opposition. It eventually removed the last remaining obstacle to EU accession negotiations by cooperating with the ICTY to facilitate the arrest of General Ante Gotovina.

The key common point in all these examples is that changes in democratization patterns in response to EU demands required a prior change in government for EU to have an impact. As Geoffrey Pridham puts it, "European designing of democracy follows rather than precedes the establishment of and first efforts in creating new liberal democracies." ${ }^{28}$ While the literature therefore largely agrees that EU influence on democracy required prior domestic change, debate persists on whether the EU itself played a role in bringing about the electoral defeat of nationalist/authoritarian governments.

Some authors argue that the EU's causal influence on national elections has been extremely limited. ${ }^{29}$ In this view, since the EU's influence is limited to the intergovernmental channel, it was powerless when faced with an authoritarian/nationalist leadership. Its inability to mobilize societal actors and voters against such governments restricted it to waiting for favorable developments in domestic politics that would bring to power liberal democratic parties for which the EU's political conditions did not impose prohibitive costs. Rather than EU influence, the outcome of such watershed elections then reflected domestic factors, such as party strategies on electoral pacts as in 
Slovakia's 1998 election, ${ }^{30}$ or voter dissatisfaction as in 2000 with the Croatian government's record on the economy and corruption.

However, even if the EU did not directly influence voters' choices and the outcome of elections, it might have influenced domestic politics indirectly. ${ }^{31}$ By contributing to the creation of a more competitive political systems in illiberal states, it pushed them to a liberal political trajectory. The EU empowered liberal reformers by informing electorates about the implication of their choices for the country's accession prospects. The EU could also influence successful electoral strategies. It fostered cooperation among a hitherto fragmented opposition by providing a common platform. The need for a common platform also induced a moderation of opposition forces through alignment of their programs with the EU's agenda of democratization. In this way, the EU also influenced which ideological outlook was shared by the elites that won power in watershed elections.

Maybe one of the clearest attempts by the EU to influence the outcome of key elections is its change of strategy with regard to conditionality vis-à-vis Serbia. The EU initially made the signing of an association agreement conditional on full cooperation with the ICTY, which had long been the subject of conflict between Vojislav Koštunica, the nationalist president of the (Serbian and Montenegrin) Federal Republic of Yugoslavia, and Zoran Djindjić, the pro-European Serbian prime minister. After Djindjić's assassination in March 2003, parliamentary elections at the end of the year resulted in a minority government led by Koštunica, which effectively put an end to cooperation with the ICTY. The EU eventually carried out its threat to suspend the ongoing negotiations for the association agreement if the Serbian 
government failed to extradite Bosnian Serb General Radko Mladić to the ICTY. Yet after the pro-European Boris Tadić won re-election in the presidential election in January 2008, the EU signed the agreement in April (while keeping its implementation conditional on cooperation with the ICTY). This move was intended to signal to the electorate the tangible benefits of a victory of Tadić's electoral coalition For a European Serbia $\left(Z_{E}{ }^{32}\right)$ in the parliamentary elections in May. Tadić successfully framed the election as a referendum on Serbia's European integration and his electoral bloc won the election, which enabled it to form a coalition government.

The Serbian parliamentary elections of 2008 are an example not only of the EU's influence on national elections, but also of how the government change that it brought about can serve to lock-in compliance with its conditions. Since both the presidency and government were now held by proEuropean parties, the Serbian authorities fully cooperated with the ICTY, arresting and extraditing the four remaining high-profile Bosnian Serb indictees during 2008 and 2011. Significantly, Serbia stayed the course for EU accession even after Tomislav Nikolić, the then deputy leader of the nationalist Serbian Radical Party $\left(\mathrm{SRS}^{33}\right)$ whom Tadić had narrowly defeated in the 2008 presidential election, won both the presidential and parliamentary elections in 2012. In the meantime, Nikolić had formed a break-away party from the SRS, the Serbian Progressive Party, in opposition to the staunch rejection of EU membership by the SRS leader, Vojislav Šešelj. Despite remaining staunchly opposed to the independence of Kosovo, in view of the progress made towards EU accession in the preceding years, Nikolić 
removed the last remaining obstacle to starting accession negotiations by agreeing to 'normalize' relations between Serbia and Kosovo.

\section{Variation in EU influence on ECE accession countries and current candidate countries in SEE}

The above discussion about variation in the EU's influence on democratization therefore reminds us not to overstate the EU's influence on democratization. One the one hand, it is typically powerless when faced with authoritarian leaderships until domestic change occurs. On the other hand, we must be careful not to attribute all cases of successful democratization to the EU's influence. At the same time, it was arguably during the period leading to the EU's eastern enlargements of 2004 and 2007 that the EU's influence on democratization through conditionality was strongest. Compared to the ECE countries that joined the EU in these enlargement rounds, progress with democratization and the establishment of the rule of law has been more modest, and the EU's influence on it more limited, in the current candidate countries in SEE since 2007.

One explanation for this difference - just as for the variation discussed in the section above - is that the adjustment costs to the EU's political conditionality are much higher in SEE than they were in CEE. On the one hand, starting conditions in SEE were generally less favorable, with lower levels of democratization as SEE countries embarked on post-communist transition and/or new statehood. Higher levels of corruption on average also means that governments in SEE have needed to forego more rent-seeking opportunities in order to meet the EU's conditions with regard to the rule of 
law. Moreover, the EU's political conditions were arguably much more demanding in SEE, especially in the successor states of Yugoslavia that had been involved in violent ethnic conflict. EU conditions designed to address the legacies of the conflict, such as the establishment of good neighborly relations or cooperation with the ICTY, went to the core of questions of national identity. ${ }^{34}$ For nationalist governments, this put compliance with EU conditions at odds with their core beliefs, while moderate nationalists had to fear an electoral backlash that could cost them their office.

The other main factor that makes EU influence on democratization less effective in SEE since 2007 is directly related to how the EU uses conditionality: the credibility of EU conditionality has diminished considerably for the countries in SEE compared to those in ECE.

The credibility of membership conditionality until the 2004/07 enlargements

In general, for the EU's conditional offer of membership to sway domestic cost/benefit calculations in favor of compliance, the offer has to be credible. ${ }^{35}$ Credibility implies both that a target country has to be certain that the EU will deliver on awarding the promised benefits, and that these benefits will be only delivered in response to compliance with the conditions set. Generally, the literature agrees that key elements of a credible conditionality are its consistent and merit-based application, as well as unambiguous messages from EU actors about what target states need to do in order to obtain the reward, and a clear consensus that the reward will be paid out when the conditions are met. ${ }^{36}$ 
By and large, the EU has applied democratic conditionality fairly consistently in the period leading to the $2004 / 2007$ enlargements. Most importantly, this referred to the willingness of the EU to grant membership to candidates that met the conditions. Initially, the reluctant and incremental nature with which the EU's policy on eastern enlargement evolved in the face of strong reservations in many EU member states, put the EU's commitment to offering accession into question.

In view of the doubts in candidate countries about the member states' willingness to enlarge the EU, the main act that made the membership perspective credible to candidate countries was the opening of accession negotiations ${ }^{37}$ Officials in the Commission suggest that opening accession negotiations is the most important stage of the enlargement process, "because opening them implies a willingness to conclude them."38 Candidate countries often complied with domestically contested issues only in the final stages of the accession process, such as in the case of the Latvian election law with regard to language requirements for candidates. When such issues were the main remaining stumbling block on the road to membership, it was highly credible that compliance would be rewarded with accession.

The importance of accession negotiations for the credibility of conditionality also explains why the candidate countries carried out difficult adjustments if the EU made the opening of accession negotiations conditional on the fulfillment of specific political conditions. Examples include the cooperation of the Croatian government with the ICTY over the arrest of General Gotovina, which had been the main obstacle to the start of negotiations, or the revision of the Latvian state language law according to EU 
demands. This successful influence was due to the credibility of the promise to eventually grant membership in return for compliance.

Moreover, the EU has been fairly consistent with regard to making fulfillment of democratic conditions the precondition for opening accession negotiations. A clear example is the decision by the European Council to exclude Slovakia from the group of countries opening accession negotiations in 1998 - despite sufficient progress with economic and legal adjustment due the shortcomings of democracy under the Mečiar regime. Another example was the EU's postponement of opening accession negotiations with Croatia that had been scheduled for March 2005. The postponement resulted from the government's failure to cooperate fully with the ICTY in the arrest of General Ante Gotovina, who had been indicted for war crimes during the military operations that expelled the Krajina Serbs in 1995. After the ICTY's then Chief Prosecutor, Carla Del Ponte, confirmed that the Croatian government fully cooperated, the EU opened accession negotiations in October 2005 (and Gotovina was arrested in the Spanish Canary Islands in December 2005 with the active assistance of Croatian security agencies). ${ }^{39}$

While the general consensus in the EU on the potential membership of the candidates in CEE was the key aspect that made membership conditionality during this period credible, there were some country- and issuespecific shortcomings in applying conditionality consistently, and these often manifested themselves in diminished EU influence. For example, the decision to include Bulgaria and Romania in accession negotiations in 2000 cast doubts about the merit-based application of conditionality, since it arguably owed more to their support for NATO's intervention in Kosovo, than to their 
progress with meeting the EU's conditions. Questions have also been raised whether the EU has been consistent in its criticisms of undemocratic practices. For example, EU representatives did not criticize Sali Berisha's autocratic style and alleged rigging of the 1996 Albanian election due to his perceived contribution to maintaining stability in the country. ${ }^{40}$ Finally, the credibility of conditionality in specific issue areas was low if the EU failed to make it subject to clear conditionality. For example, between 1997 and 1999, the EU did not attach explicit conditions to changes in Estonia's controversial language requirements for candidates in national elections, in contrast to the criticism from the OSCE High Commissioner for National Minorities, as well as to the EU's conditionality with regard to citizenship for stateless children. ${ }^{41}$

An example of the importance of the credibility of the threat of exclusion is the case of Cyprus. The EU's promise not to make accession dependent on the unification of the island was meant to deprive the Turkish Cypriot leadership of a de facto veto over Cypriot membership. Instead, it undermined the credibility of any pressures on the Greek Cypriot community to compromise over a settlement, leading it to reject the Annan plan for the unification of the island. It was therefore to little avail that the credible threat of exclusion worked on the Turkish Cypriot community, which supported the plan despite its long-standing resistance to international pressures for doing so.

The credibility of membership conditionality after the 2007 enlargement

In contrast to the generally high credibility of the EU's membership incentive for the countries joining in 2004/2007, the EU has been significantly 
weakened its credibility for the remaining accession countries in SEE. On the one hand, the EU was relatively much faster in accepting the countries in SEE as potential candidates at an early stage in their accession process in 2003 , than it had been with ECE countries. On the other hand, starting from 2005, and especially after the accession of Bulgaria and Romania in 2007 and the financial crisis of 2008, enlargement fatigue in the EU has diminished the credibility of the prospect of further EU enlargement.

Public opinion on EU enlargement, particularly among the older member states, has become more resistant over time. ${ }^{42}$ Public opposition, especially related to labor migration from new members, and a perception that the accession of Bulgaria and Romania had been premature in view of the persistence of governance problems, especially with corruption, has made member state governments more reluctant to consider further enlargement. In the European Commission, enlargement has also clearly dropped far down the agenda. The Commission President, Jean-Claude Juncker, found it opportune to state explicitly that no enlargement would take place during his presidency (which would have been highly unlikely anyway) and the Commission has since abolished the post of a designated Commissioner for Enlargement.

The change in the EU's commitment to enlargement has been most pronounced with regard to Turkey, even before the AKP government's drift toward authoritarianism. Prior to the opening of negotiations with Turkey in 2005, some member state governments, particularly in France and Austria, argued that negotiations might not necessarily lead to accession, but to another form of "privileged partnership". Moreover, subsequent amendments 
to the French constitution required all EU enlargements (after Croatia) to be approved by referendum, or a 3/5 majority of both houses of parliaments meeting in congress. These developments greatly reduce the credibility of the EU's promise to grant accession if Turkey met the conditions, and by extension the incentive for the Turkish government to do so.

While Turkey is the most striking example, the EU's more cautious approach to enlargement has led to a weakening of the membership prospect for other current candidate countries in SEE too. Especially the prospect of referenda in current member states about accession means that candidate countries cannot be sure that the EU will accept them even if they meet all the accession criteria. This uncertainty has triggered a vicious circle in which the EU has lost much leverage over domestic reforms, and a slowdown and even reversal of domestic reforms has in turn rendered the prospect of membership more remote. The EU's diminished commitment to enlargement has affected the accession prospects of individual countries differently, depending both on the attitudes towards them among the member states and on the specific domestic conditions in the candidate country.

Macedonia is arguably the most striking example of the negative impact that the diminished credibility of the membership prospect had on the country's democratization trajectory and the EU's influence on it. Initially, Macedonia had been among the earlier democratizing countries in the region, complying with a number of demanding conditions that led the Commission to recommend opening accession negotiations as early as 2009 . However, the Greek government blocked this move to gain leverage in the bilateral dispute over the use of the name "Macedonia". Repeated Commission 
recommendations continued to be met by a Greek veto. The diminished prospect of accession negotiations had decreased the EU's ability to influence domestic politics and to counteract a deterioration of democracy and state capture, as exposed in the wiretapping scandal in 2015 that led to a prolonged political crisis and the fall of the government headed by Nikola Gruevski. The compromise in June 2018 between the two prime ministers on the name issue (agreeing to rename Macedonia the Republic of Northern Macedonia) has re-opened the prospect of accession negotiations, although the agreement still faces a difficult ratification process in Macedonia. At a Council meeting in June 2018 , a majority of member states were willing to open accession negotiations with Macedonia (and Albania), in view of their progress with improving the rule of law and fighting organized crime. But especially due to opposition from The Netherlands and France, they only agreed to do so by the end of 2019 , depending on further progress in the two countries. ${ }^{43}$

Montenegro and Serbia are both involved in accession negotiations (since 2012 and 2014 respectively). Serbia especially made the politically difficult steps of arresting and extraditing indicted (Bosnian) Serb war criminals to the ICTY and of "normalizing" up to a point relations with Kosovo in order to start accession negotiations. Yet while both countries have made some modest progress with democratic governance, it has been slow. In both countries, progress has recently stagnated or even deteriorated as the credibility of EU accession diminished. Bosnia-Herzegovina and Kosovo the latter has not been recognized by all EU member states -- show not only 
the limits of the EU's influence on democratization, but also a failure of EU state-building through conditionality. ${ }^{44}$

The exception to the vicious circle of diminished credibility of accession conditionality, reduced EU influence on domestic change, and a deterioration of democratization in SEE is Croatia, which joined the EU in 2013. The HDZ government complied with the EU's requirement to cooperate with the ICTY in the arrest of General Gotovina to start accession negotiations. It then demonstrated its determination to fight corruption - an EU priority for closing negotiations - by arresting Ivo Sanader, who had served as Prime Minister from 2003 to 2009, on corruption charges, leading to a prison sentence in 2012.

\section{The sustainability of the EU's influence on democratization after accession}

The EU's influence on democratization was thus generally much stronger on the countries in ECE that joined the EU in 2004 and 2007 than in the current candidate countries. Yet there are signs that, even among these countries, the EU's influence on democratization may not be sustainable after they have obtained EU membership. Locking in democratic change through the incentive of EU membership always entailed the risk of a reversal once accession was achieved. ${ }^{45}$ Early studies found little evidence to support this concern during the first half decade of EU membership of post-communist

countries. ${ }^{46}$ Over the course of the years since 2010 , however, the picture has changed significantly. The two dramatic examples of democratic backsliding are Hungary under the Fidesz government (since 2010) and 
Poland under the Law and Justice (PiS ${ }^{47}$ ) government (since 2015). How effective is the EU in preventing a consolidation of illiberalism in these countries?

\section{Democratic backsliding in the EU's new member states}

In Hungary, Fidesz won the 2010 parliamentary election with 52.73 percent of the vote, which was sufficient for a supermajority of $2 / 3$ of the seats in parliament allowing that party to change the constitution without the support of any other party. What followed is an unprecedented concentration of power in the hands of Victor Orbán's government. ${ }^{48}$ Through constitutional and legislative changes as well as a packing of (para)public institutions with party loyalists, Fidesz eliminated checks and balances. It suspended the independence of the judiciary, curbed the role of the constitutional court, eliminated pluralism and independence of the media, and changed the electoral system to ensure supermajorities in subsequent elections against a fragmented opposition. Orbán's self-declared creation of an "illiberal democracy" followed a novel strategy of suspending liberal democratic principles without formally breaking the law. The unique opportunity offered by the constitution-changing majority enabled Fidesz to pursue an ingenious strategy of creating an illiberal "Frankenstate"49 - individual components of which do not obviously fall short of formal democratic criteria and may be justified with similar practices elsewhere, but in their sum undermine liberal democratic pluralism most fundamentally.

In Poland, the national-conservative PiS won an absolute majority in the parliamentary elections in October 2015 with 37.58 percent of the vote. 
Yet despite lacking the constitution-changing majority that Fidesz had in Hungary, it pursued a very similar strategy of concentrating power by establishing government control over the judiciary and curbing the independence of the media. ${ }^{50}$

Finally, a more straightforward case of a serious violation of the rule of law occurred in Romania, although it remained largely a temporary episode. In 2012, a new government coalition, led by Victor Ponta's Social Democratic Party $\left(\mathrm{PSD}^{51}\right)$ committed various breaches of the rule of law in attempting to impeachment Ponta's party-political rival, the center-right president Traian Basescu. ${ }^{52}$ These measures included an unconstitutional use of emergency ordinances, curbing the powers of the constitutional court and changing the constitutional requirement of a 50 percent turnout in the referendum that had to confirm the impeachment.

The scope and limits of the EU's ability to redress democratic backsliding

The EU has been not only been unable to prevent these breaches of liberal democratic governance from occurring in the first place. It has also proved largely unable to continuing acting as a force for democratization after accession by redressing democratic backsliding. ${ }^{53}$ In the case of Hungary, the EU has been generally very slow even in criticizing the Hungarian government openly and has only recently started to consider taking action. So far, it has only had been able to influence domestic changes to reverse illiberal policies in the margins. In Poland, EU institutions have been faster and more active in reacting to the breaches of liberal democracy by the PiS government, but also have not been able to exercise much influence so far. 
One exception to this bleak picture is the case of Romania. ${ }^{54}$ The Romanian government broadly complied with a list of demands by the EU to redress its breaches of the rule of law. The limited influence of the EU can be explained by the limited credibility of the EU's (negative) incentives, while differences in adjustment costs explain the main variation of EU influence across the country cases.

Prior to accession, the success of EU conditionality in supporting democratization depended both on its ability to offer a sufficiently large incentive - EU accession - to overcome domestic adjustment costs, and on the credibility of this incentive. After accession, the EU can no longer offer (equally sizeable) positive incentives for continued compliance with liberal democratic norms, but it can threaten sanctions. Again, these negative incentives also have to be credible, and arguably this is precisely the weakness of the post-accession incentive structure with regard to protecting liberal democracy.

Although the incentives that the EU can offer for compliance with its liberal democratic rules are much stronger prior to accession than after accession, EU institutions nonetheless can use potentially far-reaching sanctions with regard to violations of liberal democracy. Article 7 TEU allows the Council to "suspend certain ... rights" of a member state for "serious and persistent' breaches. The problem is that the credibility of the threat of sanctions is low. The credibility of EU sanctions depends largely on the autonomy of EU institutions, such as the Commission, the European Parliament (EP), and the European Court of Justice (ECJ), in triggering their imposition. However, this autonomy is extremely limited, as it is the member 
states themselves who determine by unanimity (minus one) whether such a breach has occurred. The Hungarian government has already reassured the Polish government that it would use its veto to prevent the determination of a violation in Poland. Moreover, the ability of the EP to play a role in triggering the Article 7 procedure, or even simply to criticize illiberal governments, has been curtailed by party politics. ${ }^{55}$ The European Peoples Party (EPP), the political group of the EP in which Fidesz is a member, has largely shielded the Hungarian government from criticism. At the same time, however, the Polish PiS, as a member of the much smaller European Conservatives and Reformists group and a partisan rival of the EPP, has been more vulnerable to sanctions in the EP. Still, the high threshold for triggering Article 7 and the high degree of control of member states greatly diminish the threat of sanctions, even if they are potentially very strong.

The credibility of sanctions also explains why the EU was more successful when it attempted to influence illiberal practices in Hungary in specific issue areas that had a separate basis in secondary EU legislation. In these areas, Articles 258 and 260 TFEU give EU institutions high autonomy in imposing sanctions: the Commission can launch infringement procedures independently and the ECJ can ultimately impose financial penalties against persistent non-compliance. In January 2012, the Commission started infringement procedures against Hungarian legislation in three areas: the lowering of the retirement age of judges from 70 to 62 (used to replace a generation of judges with new party-loyal judges, and which infringes the EU's directive on equal treatment in employment), as well as measures to restrict the independence of the national data protection supervisory authority, and of 
the Hungarian Central Bank respectively. The compliance process was still drawn out and the Commission's victory in this case may well have been pyrrhic as the political damage had been done by then (judges forced into retirement were typically compensated, but not reinstated). But these cases demonstrates that with credible material sanctions, EU institutions can maintain some leverage over specific aspects of democratic practice in the member states.

While the limited credibility of the EU's negative incentives explains well its general weakness in addressing backsliding after accession, differences in the domestic adjustment costs explain the contrast between its failure in Hungary and Poland, and its qualified success in the Romania case. In both Hungary and Poland, the fundamental transformation of the system of checks and balances constituted the very basis for the government to exercise power and to retain office. Concessions to the EU would fundamentally undermine the governments' ability to continue to do so. By contrast, the Romanian government broke the rule of law to impeach a deeply unpopular president who was in any case unlikely to win re-election in the following year. These measures were therefore hardly necessary to maintain or win office. Compliance with the EU's demands was then far less costly than in Hungary or Poland. In other words, the EU's ability to counteract violations of democratic practices decreases the more serious they are. ${ }^{56}$ While differences in adjustment costs to the EU's explain well the differences in EU influence across these cases, it might appear surprising that the Romanian government complied at all with the EU's demands, given the credibility deficit of sanctions. Even if the costs of compliance were not 
prohibitively high, why comply at all if sanctions are unlikely and noncompliance offers strategic advantages against political opponents? One possible explanation is that under the right conditions, social pressure might be able to allow EU institutions to continue to influence democratization in member states. ${ }^{57}$ In the case of the Ponta government, the conditions were strongly conducive for the effective use of social pressure. First, in contrast to the Hungarian case for example, the EU enjoys a high legitimacy both with the broader public and the main political parties, including Ponta's SDL. This strong legitimacy made the Romanian government more susceptible to criticism from the EU's interventions, even if it wasn't backed up with material sanctions. Second, the (then) 39-year old Ponta was a relative novice to international diplomacy, which arguably made him more vulnerable to social punishment. Finally, as mentioned above, the political costs of compliance were not too high. While the EU's ability to continue to influence democratization in its member states might be severely limited, there is at least some hope that under certain - admittedly very demanding - conditions, it can still have a some influence.

\section{Conclusions}

The conditional promise of EU membership has been a powerful tool for the European Union to promote democratization in Central and Southeastern Europe since 1989. At the same time, the influence of the EU has varied considerably over time, across issues, and across countries. The influence of conditionality has depended on the EU's ability to offer a credible membership incentive to outweigh the domestic costs of compliance with the 
EU's conditions. Its influence therefore depended crucially on favorable domestic constellations. The EU had only a very limited impact in countries with authoritarian and nationalist leaderships whose hold on power was threatened by the EU's demands. It had its most significant impact once such governments were replaced by reform-oriented parties for which compliance was less costly. In these cases, the EU facilitated a lock-in of democratic reforms even after a subsequent reversal in government.

The leverage of EU institutions decreased after most of the countries in ECE achieved EU membership in 2004 and 2007, since the sanctions at the disposal of EU institutions to punish democratic backsliding lacked credibility. The EU has been therefore largely impotent when faced with the measures taken by the governments in Hungary and Poland to concentrate power and to consolidate illiberal democracies.

Moreover, the power of EU conditionality in the remaining candidate countries in Southeastern Europe appears much more limited than in ECE. On the one hand, the domestic circumstances in SEE are generally less favorable. More severe problems with corruption and state capture, as well as political conditions that affect sensitive questions of statehood and national identity make compliance with EU conditions more costly for elites. On the other hand, the credibility of the membership perspective has suffered from signs of an enlargement fatigue in the EU after the 2007 enlargement, which in turn has led to diminished efforts in SEE to meet the EU's political conditions. As EU membership has lost its ability to serve as a focal point for democratic reforms, signs of stagnation and democratic backsliding have become apparent. 
Thus, the EU faces a number of challenges if it wants to continue to play as important a role in promoting democratization in the remaining candidate countries of Southeastern Europe and among its member states as it had played in some of the then candidate countries of ECE. With regard to SEE, if the EU wants to continue using conditionality as an instrument of democratization, it needs to offer membership unambiguously if the conditions are met. With regard to democratic practices within its membership, the EU needs to strengthen its instruments to sanction non-compliance with regard to liberal democracy, and show greater determination to use existing instruments, and to use them consistently.

\section{For further reading}

Jacoby, Wade. "Inspiration, Coalition, and Substitution - External Influences on Postcommunist Transformations", in World Politics, Vol. 58, Issue 4 (July 2006): 623-651.

Kelemen, R. Daniel. "Europe's Other Democratic Deficit: National Authoritarianism in Europe's Democratic Union." Government and Opposition, Vol. 52, Issue 2 (April 2017): 211-38;

Kelley, Judith G. Ethnic Politics in Europe. The Power of Norms and Incentives (Princeton, N.J.: Princeton University Press, 2004).

Kubicek, Paul J. (ed.). The European Union and Democratization (London: Routledge, 2003).

Pridham, Geoffrey. Designing Democracy. EU Enlargement and Regime Change in Post-Communist Europe (Basingstoke: Palgrave, 2005). 
Sedelmeier, Ulrich. "Anchoring Democracy from Above? The European Union and Democratic Backsliding in Hungary and Romania after Accession", in Journal of Common Market Studies, Vol. 52, Issue 1 (2014): 105-21.

Schimmelfennig, Frank, Stefan Engert, and Heiko Knobel. International Socialization in Europe: European Organizations, Political Conditionality and Democratic Change (Basingstoke: Palgrave, 2006).

Schimmelfennig, Frank and Ulrich Sedelmeier (eds.). The Europeanization of Central and Eastern Europe (Ithaca, N.Y.: Cornell University Press, 2005).

Schimmelfennig, Frank and Ulrich Sedelmeier. "The Europeanization of Eastern Europe: the External Incentives Model Revisited," Journal of Journal of European Public Policy, published online May 2019; DOI: https://doi.org/10.1080/13501763.2019.1617333

Vachudova, Milada Anna. Europe Undivided: Democracy, Leverage and Integration after Communism (Oxford: Oxford University Press, 2005).

\section{Endnotes}


${ }^{1}$ See for example, Valerie Bunce, Subversive Institutions: The Design and Destruction of Communism and the State (Cambridge: Cambridge University Press, 1999); Jon Elster, Claus Offe, and Ulrich Preuss, Institutional Design in Post-Communist Societies: Rebuilding the Ship at Sea (Cambridge: Cambridge University Press, 1998); Juan Linz and Alfred Stepan, Problems of Democratic Transition and Consolidation: Southern Europe, South America and Post-Communist Europe (Baltimore: The Johns Hopkins University Press, 1996); and Michael McFaul, "The Fourth Wave of Democracy and Dictatorship: Noncooperative Transitions in the Postcommunist World," World Politics, Vol. 54, No. 2 (January 2002), pp. 212-44. For exceptions, see Phillipe Schmitter, "The International Context of Contemporary Democratisation," in Geoffrey Pridham (ed.), Transitions to Democracy: Comparative Perspectives from Southern Europe, Latin America and Eastern Europe (Aldershot: Dartmouth Publishing, 1995); and Laurence Whitehead, The International Dimensions of Democratization: Europe and the Americas (Oxford: Oxford University Press, 1996). ${ }^{2}$ Wade Jacoby, "Inspiration, Coalition, and Substitution - External Influences on Postcommunist Transformations," in World Politics, Vol. 58, Issue 4 (July 2006), pp. 623-51; Judith G. Kelley, Ethnic Politics in Europe. The Power of Norms and Incentives (Princeton, N.J.: Princeton University Press, 2004); Paul J. Kubicek (ed.), The European Union and Democratization (London: Routledge, 2003); Jon C. Pevehouse, Democracy from Above: Regional Organizations and Democratization (Cambridge: Cambridge University Press, 2005); Pridham, Designing Democracy, pp. 9-11; Frank Schimmelfennig, Stefan Engert, and Heiko Knobel, International Socialization in Europe: European Organizations, Political Conditionality and Democratic Change (Basingstoke: Palgrave, 2006); Schimmelfennig and Sedelmeier (eds.), The Europeanization of Central and Eastern Europe; and Milada Anna Vachudova, Europe Undivided: Democracy, Leverage and Integration after Communism (Oxford: Oxford University Press, 2005).

3 Jeffrey Kopstein and David Reilly, "Geographical Diffusion and the Transformation of the Postcommunist World", in World Politics, Vol. 53 No. 1 (October 2000), p. 25.

${ }^{4}$ Kopstein and Reilly, p. 27, citing Magyar Nemzet (19 June 1999).

${ }^{5}$ Heather Grabbe, The EU's Transformative Power: Europeanization through Conditionality in Central and Eastern Europe (Basingstoke: Palgrave, 2006); Kelley, Ethnic Politics, Kubicek The European Union and Democratization; Pridham, Designing Democracy, Schimmelfennig et al., International Socialization; Schimmelfennig and Sedelmeier, The Europeanization of Central and Eastern Europe; Karen Elizabeth Smith, "The Use of Political Conditionality in the EU's Relations with Third Countries: How Effective?," in European Foreign Affairs Review, Vol. 3, No. 2 (1998), pp. 253-74; and Vachudova, Europe Undivided. ${ }^{6}$ Pridham, Designing Democracy. EU Enlargement and Regime Change in Post-Communist Europe (Basingstoke: Palgrave, 2005), p. 3; and Frank Schimmelfennig and Ulrich 
Sedelmeier, "Introduction: Conceptualizing the Europeanization of Central and Eastern 
Europe," in Frank Schimmelfennig and Ulrich Sedelmeier (eds) The Europeanization of Central and Eastern Europe (Ithaca, N.Y.: Cornell University Press, 2005), p. 3.

7 Pridham, Designing Democracy, pp. 31-2; and Daniel C. Thomas, "Constitutionalization through Enlargement: The Contested Origins of the EU's Democratic Identity", in Journal of European Public Policy, Vol. 13, Issue 8 (2006), pp. 1190-210.

${ }^{8}$ European Council in Copenhagen (7-8 April 1978), EC Bulletin 3/1978, p. 6.

${ }^{9}$ William Wallace, Opening the Door: The Enlargement of NATO and the European Union (London: Centre for European Reform, 1996), p. 16.

${ }^{10}$ European Council in Copenhagen, 21-22 June 1993, Conclusions of the Presidency; SN 180/93, p. 16.

${ }^{11}$ Jacoby, "Inspiration, Coalition, and Substitution"; Kelley, Ethnic Politics, Pridham, Designing Democracy, pp. 9-11; Schimmelfennig, et al., International Socialization; Schimmelfennig and Sedelmeier The Europeanization of Central and Eastern Europe; and Vachudova, Europe Undivided, passim.

${ }^{12}$ Grabbe, Transformative Power, J. Hughes, G. Sasse, and C. Gordon, Europeanization and Regionalization in the EU's Enlargement to Central and Eastern Europe: The Myth of Conditionality (Basingstoke: Palgrave, 2004), passim; Kelley, Ethnic Politics, passim; Kubicek, Democratization; Schimmelfennig et al., International Socialization; Schimmelfennig and Sedelmeier, The Europeanization of Central and Eastern Europe, passim; and Vachudova, Europe Undivided, passim.

${ }^{13}$ Kelley, Ethnic Politics, pp. 47-53.

${ }^{14}$ McFaul, "Fourth Wave"; F. Schimmelfennig, "Strategic Calculation and International

Socialization: Membership Incentives, Party Constellations, and Sustained Compliance in Central and Eastern Europe," in International Organization, Vol. 59, No. 4 (Autumn 2005), pp. 827-860; Schimmelfennig et al., International Socialization, passim; and Vachudova, Europe Undivided.

${ }^{15}$ Vachudova Europe Undivided.

${ }^{16}$ Schimmelfennig et al., International Socialization, pp. 246-7.

${ }^{17}$ Kelley, Ethnic Politics, pp. 73-93.

18 Kelley, Ethnic Politics., pp. 50-1; and Schimmelfennig et al., International Socialization, p. 248.

${ }^{19}$ Schimmelfennig, "Strategic Calculation"; Schimmelfennig and Sedelmeier (eds.), The Europeanization of Central and Eastern Europe; and Vachudova, Europe Undivided, passim.

20 Vachudova, Europe Undivided, passim.

21 From the Romanian, Partidul Democraţiei Sociale din România.

22 From the Slovak, Hnutie Za Democratické Slovensko.

${ }^{23}$ Geoffrey Pridham, "The European Union's Democratic Conditionality and Domestic Politics in Slovakia: The Meciar and Dzurinda Governments Compared," in Europe-Asia Studies, Vol. 54, Issue 2 (2002), pp. 203-27. 
24 From the Slovak, Smer - sociálna democracia.

25 From the Slovak, L'udová Strana -- Hnutie Za Democratické Slovensko.

${ }^{26}$ Geoffrey Pridham, "Status Quo Bias or Institutionalisation for Reversibility? The EU's

Political Conditionality, Post-Accession Tendencies and Democratic Consolidation in Slovakia," in Europe-Asia Studies, Vol. 60, Issue 3 (2006), pp. 423-54.

27 From the Croatian, Hrvatska Demokratska Zajednica.

28 Pridham, Designing Democracy, p. 61.

${ }^{29}$ Tim Haughton, "When Does the EU Make a Difference? Conditionality and the Accession Process in Central and Eastern Europe," in Political Studies Review Vol. 5, Issue 2 May 2007), pp. 233-46; and Schimmelfennig et al., International Socialization.

${ }^{30}$ Schimmelfennig et al., International Socialization, pp. 127-8.

${ }^{31}$ Vachudova, Europe Undivided.

32 From the Serbian, Za Evropsku Srbiju.

33 From the Serbian, Srpska Radikalna Stranka.

${ }^{34}$ See e.g. Tina Freyburg and Solveigh Richter, "National Identity Matters: The Limited Impact of EU Political Conditionality in the Western Balkans", in Journal of European Public Policy, Vol. 17, Issue 2 (2010), pp. 263-81; Gergana Noutcheva, "Fake, Partial and Imposed Compliance: The Limits of the EU's Normative Power in the Western Balkans," In Journal of European Public Policy, Vol. 16, Issue 7 (2009), pp. 1065-84.

${ }^{35}$ Schimmelfennig and Ulrich Sedelmeier, "Conclusions", passim.

${ }^{36}$ Grabbe, Transformative Power, Hughes et al. Myth of Conditionality, Schimmelfennig and Sedelmeier, Europeanization; and Vachudova, Europe Undivided, passim.

${ }^{37}$ Schimmelfennig and Sedelmeier, The Europeanization of Central and Eastern Europe.

${ }^{38}$ Graham Avery and Fraser Cameron, The Enlargement of the European Union (Sheffield:

Sheffield Academic Press, 1998), p. 27.

${ }^{39}$ At the same time however, the opening of negotiations in October 2005 prior to the actual arrest of Gotovina appeared to undermine the credibility of conditionality, especially since it appeared that the Austrian government made its consent to the opening of accession negotiations with Turkey conditional on also starting them with Croatia. However, the EU argued that by then the Croatian government had already cooperated fully with the ICTY contributing to his eventual arrest in Spain.

${ }^{40}$ Pridham, Designing Democracy, p. 59.

${ }^{41}$ Schimmelfennig et al., International Socialization, passim.

42 Dimiter Toshkov, Elitsa Kortenska, Antoaneta Dimitrova, and Adam Fagan, "The 'Old' and the 'New' Europeans: Analyses of Public Opinion on EU Enlargement in Review", MAXCAP Working Paper No. 2 (April 2014), at http://userpage.fuberlin.de/kfgeu/maxcap/system/files/maxcap wp 02.pdf [last accessed on 9 August 2018]. ${ }^{43}$ Eszter Zalan "EU delays Macedonia and Albania talks", EUobserver (27 June 2018), at https://euobserver.com/political/142197 [last accessed on 9 August 2018]. 
${ }^{44}$ Florian Bieber, "Building Impossible States? State-building Strategies and EU Membership in the Western Balkans", in Europe-Asia Studies, Vol. 63, Issue 10 (2011), pp. 1783-1802. ${ }^{45}$ Frank Schimmelfennig and Ulrich Sedelmeier, "Conclusions: The Impact of the EU on the Accession Countries", in Schimmelfennig and Sedelmeier (eds.), The Europeanization of Central and Eastern Europe, pp. 226-8; and Rachel A. Epstein and Ulrich Sedelmeier, "Beyond Conditionality: International Institutions in Postcommunist Europe after Enlargement", in Journal of European Public Policy, Vol. 15, Issue 6 (2008), pp. 795-805.

${ }^{46}$ Philip Levitz and Grigore Pop-Eleches, "Why No Backsliding? The European Union's Impact on Democracy and Governance Before and After Accession", in Comparative Political Studies, Vol. 43, No.4 (April 2010), pp. 457-485.

47 From the Polish, Prawo i Sprawiedliwość.

48 Miklós Bánkuti, Gábor Halmai, and Kim Lane Scheppele, "Disabling the Constitution", in Journal of Democracy, Vol. 23, No. 3 (July 2012), pp. 138-46.

${ }^{49}$ Kim Lane Scheppele, "The Rule of Law and the Frankenstate: Why Governance Checklists Do Not Work", in Governance, Vol. 26, No. 4 (October 2013):559-62.

${ }^{50}$ See e.g. R. Daniel Kelemen and Mitchell A. Orenstein "Europe's Autocracy Problem: Polish Democracy's Final Days?", in Foreign Affairs, (7 January 2016).

51 From the Romanian, Partidul Social Democrat.

52 Ingi Iusmen, "EU Leverage and Democratic Backsliding in Central and Eastern Europe: The Case of Romania", in Journal of Common Market Studies, Vol. 53, Issue 3 (first published on 24 August 2014), pp. 593-608; Grigore Pop-Eleches, "Learning from Mistakes: Romanian Democracy and the Hungarian Precedent", in Newsletter of the European Politics and Society Section of the American Political Science Association (Winter 2013), pp. 9-12.

${ }^{53}$ See e.g. Michael Blauberger, and R. Daniel Kelemen, "Can courts rescue national democracy? Judicial safeguards against democratic backsliding in the EU", in Journal of European Public Policy, Vol. 24, Issue 3 (2017), pp. 321-336; Carlos Closa and Dimitry Kochenov (eds.), Reinforcing Rule of Law Oversight in the European Union (Cambridge: Cambridge University Press, 2016); Laurent Pech and Kim Lane Scheppele, "Illiberalism Within: Rule of Law Backsliding in the EU," Cambridge Yearbook of European Legal Studies 19 (2017), pp. 3-47; R. Daniel Kelemen, "Europe's Other Democratic Deficit: National Authoritarianism in Europe's Democratic Union", in Government and Opposition, Vol. 52, Issue 2 (April 2017), pp. 211-38; Ulrich Sedelmeier, "Anchoring Democracy from Above? The European Union and Democratic Backsliding in Hungary and Romania after Accession", in Journal of Common Market Studies, Vol. 52, Issue 1 (first published on 10 December 2013), pp. 105-21; Ulrich Sedelmeier, "Political safeguards against democratic backsliding in the EU: the limits of material sanctions and the scope of social pressure," Journal of European Public Policy, Vol. 24, Issue 3 (2017), pp. 337-351.

${ }^{54}$ Iusmen, "EU Leverage"; Sedelmeier "Anchoring Democracy". 
${ }^{55}$ Kelemen, "Europe's Other Democratic Deficit"; Sabina Avdagic and Ulrich Sedelmeier, "Voting for punishment: the party politics of sanctioning democratic backsliding in parliamentary assemblies of Regional IOs", paper presented at the International Studies Association Annual Convention, 4-7 April 2018, San Francisco; Ulrich Sedelmeier "Protecting Democracy inside the European Union? The Party Politics of Sanctioning Democratic Backsliding in the European Parliament", MAXCAP Working Paper No. 27 (2016) available at http://userpage.fu-berlin.de/kfgeu/maxcap/system/files/maxcap wp 27.pdf

56 Sedelmeier, "Political safeguards", passim.

${ }^{57}$ Sedelmeier "Anchoring Democracy", pp. 114-118; and Sedelmeier, "Political safeguards", passim. 